Marketing in Asia Group

\title{
Dependence Structure, Trust Dimensions, and Governance Choices in Asian Marketing Channels: Evidence in China
}

\author{
Lucy Sojung Lee \\ Department of Management, SNU Business School, Seoul National University, Seoul \\ Guanghua School of Management, Peking University, China \\ Weiguo Zhong \\ Department of Organization and Strategy, Guanghua School of Management, Peking \\ University, China
}

\begin{abstract}
Building on three decades' worth of theoretical work on firm dependence structure and firm governance strategy, from a dyadic perspective we investigate the mediating effects of different facets of interorganizational trust (competence trust and benevolence trust) on firm governance choices. We posit that firm dependence may evoke different facets of trust, which in turn lead to the firm's choice of different governance mechanisms (contractual bonds and relational exchange). Using Chinese supplier-buyer dyads and the novel actor-partner interdependence model, we find strong support for such intermediate effects of trust dimensions on the relationships between dependence structure and governance choices from both supplier and buyer data. Practical implications for Asian business are discussed, and directions for future research are suggested.
\end{abstract}

Keywords: Dependence; Competence Trust, Benevolence Trust, Contractual Bonds, Relational Exchange, Actor-Partner Interdependence Model

Publication Details: Received 15 Feb 2020; Revised 12 Mar 2020; Accepted 3 Apr 2020 


\section{Introduction}

Interorganizational relationship (IORs) are critical to firm competitive advantages (Ring \& Van de Ven, 2019). However, not both sides of IORs are good and researchers have paid increasing attention to the dark side of IORs such as power imbalance (Oliveira \& Lumineau, 2019) and trust divergence (Brattström et al., 2019; Kujala et al., 2015). The dark side of IORs makes the governance mechanisms be dysfunctional (Eckerd \& Girth, 2017; Howard et al. 2019). Then, how firms can design effective governance mechanisms under the conditions of power imbalance and trust divergence become an issue important for firms to leverage IORs for firm performance. Previous literature argues that the choice of governance mechanisms depends on firms' perceptions of risks, such as performance risk and/or relational risk, involved in the interfirm relationships (Das \& Teng, 2001; Heide, 1994). Moreover, firm dependence structure is one of the most important determinants of firm governance choices because it affects firm risk perceptions (Gulati \& Sytch, 2007; Xia, 2011; Zheng et al., 2020). As such, the relationship between firm dependence structure and governance mechanism has been intensively investigated over the past three decades (Gilliland, Bello \& Gundlach, 2010; Lusch \& Brown, 1996; Petersen et al., 2008; Roehrich et al., 2020; Terpend \& Krause, 2015).

Two streams of theories have been heavily employed to explain firm governance choice. One is transaction cost economics, which proposes that firms may use contractual bonds in response to exchange hazards caused by dependence disadvantages, such as resource dependence and locked-in dependence resulting from specific investment (Colm et al., 2020; Mayer \& Argyres, 2004; Williamson, 1985). The other is relational governance theory, which recognizes the usefulness of contracts but further asserts that relational governance is more effective in coping with dependence disadvantages (Chatterji et al., 2019; Dyer \& Singh, 1998; Gulati, 1998; Heide \& John, 1992; Poppo \& Zenger, 2002).

Although empirical findings shed much light on firm governance strategies, several significant gaps persist from a careful review of prior work. First, while many studies have empirically examined the relationship between dependence structure and governance choice, few have explored the intermediate mechanisms by which dependence concerns generate firm governance strategies (Leonidou et al., 2019; Lusch \& Brown, 1996; Palmatier, Dant, \& Grewal, 2007).

Second, little attempt has been made to inherently link dependence and trust to explain firm governance choices or to understand the effects of dependence on different dimensions of trust (McEvily et al., 2017; Zhong et al., 2017). Very few, if any, researchers have considered dependence structure a primary source of trust that may prime differential trusting relationships. A firm will try to build a relationship with others when it perceives a need for resources and support from other firms (Oliveira \& Lumineau, 2019; Pfeffer \& Salancik, 1978). Different forms (dependence vs. interdependence) and degrees (shallow vs. deep dependence) of dependence may lead to different contents and levels of trust (Brattström et al., 2019; Sheppard and 
Sherman, 1998). Therefore, trust production varies according to dependence of the trusting parties. The effect of dependence on trust, especially on different dimensions of trust, is thus worthy of further theoretical exploration.

Third, although trust is inherently multidimensional (McEvily \& Zaheer, 2006; Ogbeibu et al., 2018), only more recently researchers have started to discern its dimensions and their differential effects on governance choices. Although trust is important, we may want to continue "If firm A trusts firm B, it actually trusts what aspect of firm B, its competence (e.g., ability to produce the desired outcomes) or its benevolence (e.g., goodwill to consider A's interest)?" The divergence of trusts across dimensions is critical to interorganizational cooperation (Brattström et al., 2019). Without differentiating the trust dimensions, we cannot infer whether more trust is good or bad (Villena et al., 2019). Thus, incorporating the different dimensions of trust such as competence-trust and benevolence-based trust may provide more insights into the design of governance mechanisms (Malhotra \& Lumineau, 2011).

Finally, most research contexts in the literature are dyadic partners; yet most studies have neglected the problem of nonindependence rooted in the dyadic data (Bstieler et al., 2017). One defining feature of relational data collected from cooperative dyads is nonindependence; that is, measurements reflect not only the characteristics of the actor who provides the score but also the characteristics of the actor's partner (Bstieler et al., 2017; Kenny et al., 2006). Although some studies have built theory from a dyadic view and collected data from both sides, few have addressed such behavioural correlation and considered both members in a dyad simultaneously in the estimation of empirical models (Bstieler et al., 2017). As such, analysis of dyadic data from one side has overlooked specific dyadic variance and thus ignored the nonindependence of the two dyadic scores (Yakovleva et al., 2010). Consequently, conventional statistical procedures (e.g., analysis of variance, linear regression) without considering such nonindependence may be misleading because the resulting test statistics and degrees of freedom will be inaccurate and the $\mathrm{p}$ values will be biased (Cook \& Kenny, 2005).

To address these research gaps, we introduce the power-dependence logic into the choices of governance mechanisms and develop a conceptual model (see Figure 1) to examine the direct effect of dependence structure on governance choices, the mediating effects of competence and benevolence trust, and the interaction effect of supplier and buyer dependence. We use the actor-partner interdependence model (APIM) (Kenny et al., 2006) to estimate simultaneously both the supplier and the buyer effects. In doing so, we echo Lusch and Brown's (1996) summons to introduce trust into the dependence-governance relationship and contribute to the literature in three aspects: (1) We examine the inherent relationship between dependence structure and trust dimensions, (2) we retrieve the missing linkage between dependence and governance to enrich our understanding of firm governance choice behaviour, and (3) we examine the dependence-governance relationship using a dyadic model of the supplier-buyer dyad. 
Figure 1: A Model of Trust Dimensions in Channel Governance Choices

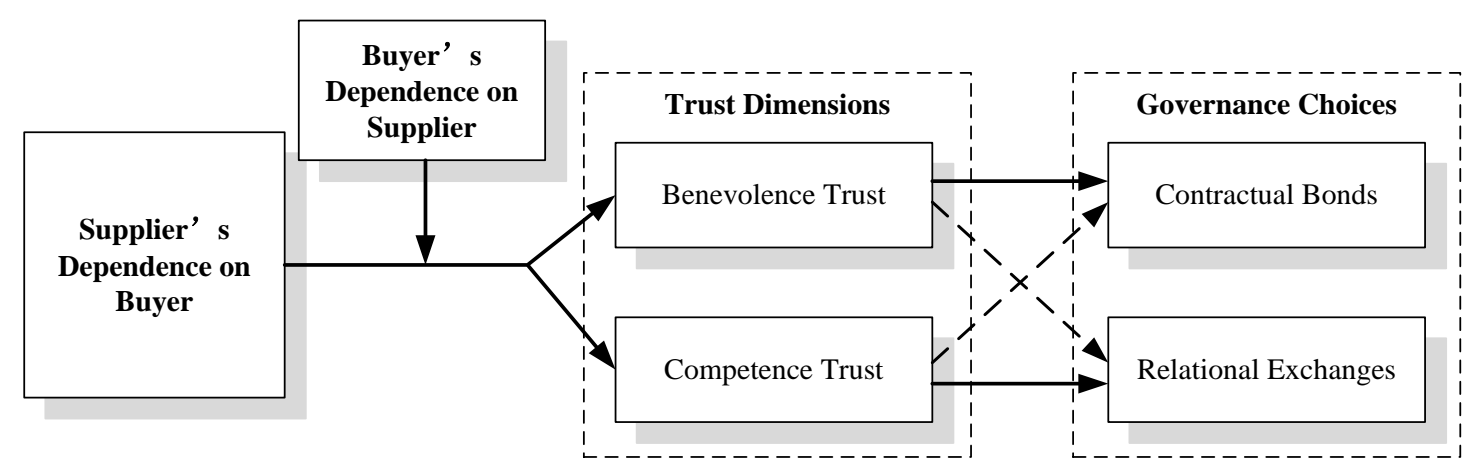

Conceptual Development and Hypotheses

\section{Dependence and Governance Choices}

Dependence is the extent to which a target firm needs the source firm to achieve its desired goals (Emerson, 1962; Frazier, 1983). Two important factors create a perception of dependence: (1) the importance of the resources (capabilities) provided by the source firm and (2) the number of alternative sources available to the target firm for the needed resources (capabilities).

Dependence structure is one of the most important determinants of firm governance choices (Gulati \& Sytch, 2007; Heide \& John, 1992; Lusch \& Brown, 1996; Su et al., 2009; Zheng et al., 2020). Although the empirical results are not compatible, we argue that in a supplier-buyer relationship dyad, the less dependent supplier is more likely to build contractual bonds with the buyer to safeguard performance, whereas the more dependent supplier tends to use relational exchange with the buyer to safeguard against opportunism.

First, a less dependent supplier is concerned more about performance risk than about relational risk (e.g., opportunism) because the more dependent buyer might be unable to perform its expected tasks. As it becomes difficult to check and monitor the buyer's competence and predict its behaviours in a turbulent market, the potential for performance risk increases while bounded rationality prevents the supplier from detecting it (Poppo \& Zenger, 2002). Contractual bonds serve to reduce performance uncertainty of the more dependent partner (e.g., the buyer) and thus mitigate the problem of free-riding, such as when the weaker buyer is unable to fulfil its end of a deal (Oliveira \& Lumineau, 2019; Williamson, 1985). An example would be franchise contracts that are written to extract safeguards in favor of the franchisor (Brattström et al., 2019; Lusch \& Brown, 1996). Second, contractual bonds function to ensure legitimacy of the less dependent supplier that monitors the buyer's activities. Legitimacy, originating from institutions, includes any form of constraints that human beings devise to shape their behaviours (North, 1990). The contractual bonds between the supplier and the buyer serve as the institution specifying cognitive and 
behavioural norms in the dyad. Thus, the supplier can ensure buyer compliance through such contractual bonds to gain the legitimacy of its monitoring (Heide, 1994). Third, contractual bonds function to technically control and coordinate the weaker buyer's activities by specifying terms and parameters on incentives, roles, and responsibilities (Carson, Madhok, \& Wu, 2006; Krishnan, Martin, \& Noorderhaven, 2006; Luo, 2002; Mayer \& Argyres, 2004; Zheng et al., 2020), thereby mitigating the supplier's concern about the competence of the buyer in a transactional relationship. Therefore, we propose the following:

H1a The less the supplier is dependent on the buyer, the more the supplier tends to develop contractual bonds with the buyer.

However, when the supplier's dependence on the buyer increases, the supplier may conduct more relational exchanges with the buyer. This is because when the supplier becomes more dependent, its contract-based control may become impotent and its influence attempts will be less effective because the stronger buyer has (1) more power to extract allowances and negotiate more favourable terms (Payan \& McFarland, 2005), (2) less necessity to absorb constraints from the more dependent supplier to maintain the relationship (Casciaro \& Piskorski, 2005), and (3) little motivation to forbear the supplier's control attempts (Kumar et al., 1995). Therefore, the weaker supplier must conduct more relational exchanges with the less dependent buyer to maintain the long-term relationship (Ganesan, 1994; Howard et al., 2019; Poppo \& Zenger, 2002).

Conversely, calculative commitment, originating from the perception of the need to preserve the relationship, also drives the weaker supplier to proactively conduct more relational exchanges (Gustafsson, Johnson, \& Roos, 2005; Kale, Singh, \& Perlmutter, 2000) to safeguard against the stronger buyer's exploitative use of decision rights (Ganesan, 1994; Heide \& John, 1992). For example, in a turbulent market environment such as China, the weaker suppliers proactively cultivate relational bounds (e.g., guanxi) with powerful others to obtain favors or protections (Colm et al., 2020; Su et al., 2009; Zhou \& Poppo, 2010; Zhuang \& Zhou, 2004). Such relational actions function to establish a perception of 'insiders,' which results in social and economic capital and, thus, greater competitive advantages (Gu et al., 2010; Dekker et al., 2019). Based on the above argument, we propose the following:

H1b The more the supplier is dependent on the buyer, the more the supplier tends to develop relational exchanges with the buyer.

\section{Dependence Structure and Trust Dimensions}

Notably, trust exists between partners depending on the extent to which one partner believes the other is benevolent and honest (Anderson \& Narus, 1990; Ring \& Van de Ven, 1992). However, these two dimensions are so closely related that prior research has tended to treat trust as a global measure (Heyns \& Rothmann, 2015). Andaleeb (1992) adds capability or competence as another dimension to the construct because a transactional relationship entails not only goodwill but also capability. Ganesan 
(1994), Nooteboom (1996), and Doney and Cannon (1997) conceptualize interfirm trust as having two separate dimensions: (1) credibility, which refers to the buyer's belief that the supplier has the required ability to carry out its role effectively and reliably, and (2) benevolence, which refers to the buyer's belief that the supplier also consider the buyer's interest. We follow this conceptualization to conceive trust as having two basic elements in a transactional relationship: A's perception of B's ability to produce the desired outcomes (i.e., competence trust), and A's perception of B's goodwill to consider A's interest (i.e., benevolence trust).

Dependence on the partner's resources, information, or capabilities has been proposed as a core requirement for the development of trust (Jia \& Yang, 2019; Rousseau et al., 1998; Zhong et al., 2017). Expectations about partner trustworthiness only become relevant when the completion of one partner's desired goals depends on the actions or cooperation of the other partner (Luhmann, 1979). The notion that dependence is one of the definitional antecedents of trust, however, has long been neglected in prior literature. The most elaborate conception of dependence is Emerson's (1962) concept that the dependence of A on B is (1) directly proportional to A's motivational investment in goals mediated by B and (2) inversely proportional to the availability of those goals to A outside the A-B relationship. Obviously, A's goals and B's appropriate actions, which facilitate the achievement of A's goals, constitute the basic blocks of dependence. Thus, dependence is rooted in A's perception that B is able to perform the relevant actions that enable A to achieve its goals (Gaski, 1984). In other words, the more A depends on B, the more A trusts B in its competence (resources and capabilities). Conversely, high dependence also implies that the dependent party has fewer alternatives that it can rely on to achieve its desired objectives (Emerson, 1962; Lusch \& Brown, 1996). Alternatively, the dependent party will be less powerful in safeguarding its interest in the power game because of the no-choice dilemma, making it vulnerable to the more powerful party's opportunism. Thus, the more A depends on B, the less A trusts B in its benevolence.

In a supplier-buyer relationship, the more dependent supplier will trust the buyer more in its competence because the powerful buyer is able to help the supplier achieve its desired goals using its resources and knowledge (Chua, Morris, \& Ingram, 2009; Kumar et al., 1995; Simonin, 1999). However, the weaker supplier will have more to lose if the relationship discontinues or deteriorates (Kumar et al., 1995). Thus, increased dependence makes the supplier more vulnerable to the buyer's unilateral opportunism (Ganesan, 1994; Palmatier et al., 2007) and constrains the supplier's use of powerful tactics, such as a control-focused influence strategy. In other words, the weaker supplier must face higher risks coming from the buyer, such as indiscretion, unreliability, and cheating (Sheppard \& Sherman, 1998). The logic of power (Emerson, 1962) then alerts the supplier to the benevolence of the powerful buyer. The notion that increased dependence provides fewer structural barriers for the buyer to use coercive power makes such caution more serious (Gulati \& Sytch, 2007; McEvily et al., 2017). Thus, we propose the following: 
H2 As dependence on the buyer increases, the supplier trusts the buyer (a) more in its competence but (b) less in its benevolence.

\section{Trust Dimensions and Governance Choices}

As we previously defined, competence trust refers to the trustor's belief that the trustee possesses the needed resources and/or capabilities to fulfil the expected tasks. When the supplier trusts the buyer more in its competence, the supplier will conduct more relational exchanges with the buyer because (1) the supplier faces a high relational risk in which the buyer may not cooperate in a desired manner (Das \& Teng, 2001) and (2) the supplier is dependent on the buyer's competence to achieve its desired goals but also is concerned about unilateral buyer actions (Ganesan, 1994; Palmatier et al., 2007). To mitigate such transactional hazards, the supplier may use relationship strategies to establish relational bonds with the buyer, which function to undermine buyer opportunism (Poppo \& Zenger, 2002) and generate more relational rent (Gu et al., 2010).

Empirical evidence for such arguments abounds in previous studies (Benton \& Maloni, 2005; Brown, Lusch, \& Nicholson, 1995; Colm et al. 2020; Ramaseshan, Yip, \& Pae, 2006; Su et al., 2009). For example, Su et al. (2009) find that the more dependent supplier tends to empower more use of interpersonal relationships (e.g., guanxi) to build embedded ties with the retailer because it expects the competent retailer to provide critical resources. Brown et al. (1995) likewise find that though the more dependent manufacturer is cautious about the customer's goodwill, it is willing to accept the customer's influence and tries to establish a good relationship with the customer because it trusts the customer's capability. Therefore, we propose the following:

H3a The more the supplier trusts the buyer in its competence, the more the supplier tends to conduct relational exchanges with the buyer.

Benevolence trust refers to the trustor's belief that the trustee possesses goodwill to care about the trustor's interests. In a supplier-buyer dyad, when the supplier trusts the buyer more in its benevolence, the supplier may also be concerned about the buyer's competence in delivering the desired firm performance (Das \& Teng, 2001). Therefore, the supplier will conduct more contractual bonds with the buyer because (1) the supplier can use contractual terms and parameters to monitor and coordinate the buyer's activities and operations so as to safeguard performance (Poppo \& Zenger, 2002) and (2) though benevolence trust reduces the supplier's concern about the buyer's opportunism, the supplier may also use detailed contracts to reduce monitoring costs by increasing the specificity of transactions and clarifying the objects of cooperation (Lui and Ngo, 2004). Furthermore, the costs saved from relationship building add to the supplier's contracting effort to ensure the buyer's contribution of its fair share of resources to safeguard against performance risk (Das \& Teng, 2001). 
Prior empirical studies have also confirmed that when a supplier has benevolence trust in a buyer, the supplier believes that the buyer will not opportunistically gain at its expense (Dyer \& Chu, 2003); rather, the supplier is concerned more about the buyer's competence. Thus, the supplier will write more explicit contracts to specify and detail the obligations of each party to gain control over the buyer's behaviours and to ensure that it achieves its business objectives (Carson et al., 2006; Reuer \& Ariño, 2007; Woolthuis, Hillebrand, \& Nooteboom, 2005). Thus, we propose the following:

H3b The more the supplier trusts the buyer in its benevolence, the more the supplier tends to build contractual bonds with the buyer.

\section{The Moderating Effect of Partner Dependence}

Although several studies in the literature have acknowledged the importance of considering joint dependence or interdependence (e.g., Casciaro \& Piskorski, 2005; Gulati \& Sytch, 2007; Lusch \& Brown, 1996), no empirical study has examined the moderating effect of partner dependence on the relationship between dependence and different dimensions of trust. When the supplier's dependence on the buyer is high, as we hypothesized previously, the supplier will trust more in the buyer's competence but less in its benevolence. However, if the buyer also has a high dependence on the supplier, the channel dyad becomes mutually dependent (Casciaro \& Piskorski, 2005; Gulati \& Sytch, 2007) or deeply interdependent (Sheppard \& Sherman, 1998).

Then, the effects of unilateral dependence on the different dimension of trust may change. Specifically, the effect of the supplier's dependence on the competence-based trust will be enhanced because (1) mutual dependence may lead to a high level of interaction and communication, which are conducive to the development of cooperative interfirm relationships (Frazier, 1983; Ring \& Van de Van, 1992); (2) such relational closeness motivates both the supplier and the buyer to contribute more to the relational rent because they can invest in the specific relationship with less concern about opportunism, exchange substantial and critical knowledge and information, and supply each other with more complementary and rare resources (Hibbard, Kumar, \& Stern, 2001); (3) such interfirm cooperation facilitates organizational learning, by which the supplier can identify and appreciate more of the buyer's capability and potential contribution to the relationship (Teece, Pisano, \& Shuen, 1997).

The negative effect of the supplier's dependence on benevolence trust will be weakened, however. That is, as the buyer's dependence increases, the supplier's concern about the buyer's opportunism will lessen. This is because (1) mutual dependence reduces the two party's power difference and gives both parties equal opportunities to control each other's behaviour, and thus both the supplier and the buyer tend to invest more to maintain their relationship and avoid destructive actions (Ganesan, 1994; Hibbard et al., 2001; Lusch \& Brown, 1996), and (2) mutual dependence facilitates communication and interactions, which render the buyer's 
intention and behaviours easier to interpret or predict (Frazier, 1983; Saxton, 1997). Thus, the supplier's concern about the buyer's benevolence is alleviated.

H4a The effect of the supplier's dependence on competence trust is stronger when the buyer's dependence on the supplier is high rather than low.

H4b The effect of the supplier's dependence on benevolence trust is weaker when the buyer's dependence on the supplier is high rather than low.

\section{Method}

\section{Research Design and Data Collection}

We tested our hypotheses with a matched sample of the supplier-buyer dyads in the household appliances industry collected in Jiangsu Province, People's Republic of China. We chose such context for three major reasons. First, the household appliances industry is almost perfect competition and the marketing channels is important for the firms. Second, due to competition, the dark side of IORs is a big problem in this industry. Third, Jiangsu province is a relatively developed region in China and the household appliances industry is very active and has enough firms to be sampled. Moreover, the undeveloped legal environment also makes the governance mechanisms that firms adopt to mitigate the dark side of IORs more practically relevant.

We first used our social ties to request the intermediary services of the Administration of Industry and Commerce of Jiangsu Province (AICJ) to ensure access to the target companies and their archival data. We then randomly selected 2,000 buyer firms and called them to solicit their willingness to participate in the study. We interviewed the informants face-to-face, asked them to complete the questionnaire, and requested the name, address, and contact information of their primary suppliers. Afterward, we contacted the corresponding suppliers through the AICJ. Similarly, we interviewed two informants from each supplier company and asked them to complete the questionnaire on the supplier side.

We succeeded in collecting 595 buyer questionnaires and 550 supplier ones. After deleting the uncompleted questionnaires and pairing the supplier-buyer dyads, we had 157 usable matched questionnaires. We then gathered secondary data on the firm characteristics for both responding and nonresponding firms from AICJ to examine nonresponse bias. Several tests were conducted and found that there is nonresponse bias. 


\section{Operational Measures}

We adapted the measures used in the survey from established studies.

\section{Dependence}

We adapted four items from Lusch and Brown (1996) and Gulati and Sytch (2007) to capture the importance and irreplaceability aspects of the supplier-buyer relationships. Both the supplier and the buyer reported on how difficult or costly it would be to replace or lose their channel partner. We gathered their responses on a seven-point scale ( $1=$ strongly disagree; $7=$ strongly agree $)$, such that a higher score indicates greater dependence.

\section{Governance Choice}

We focused on two types of governance choices: contractual bonds and relational exchanges. We adapted the measure of contractual bonds from Cannon and Perreault (1999) and Lusch and Brown (1996) to examine the extent to which the contract is used in the relationship, the degree to which the contract specifies the responsibilities of each party, and how each party is to perform and deal with unexpected events. For example, items include "Specific and well-designed agreements", "Handling disagreements based on contract", "Defining the role of based on contract", "Detailed contractual agreements", "Determining remedies based on contract", and "Formal agreements detailing the obligations". We adapted the measures from Heide and John (1992) and Lusch and Brown (1996) to capture the extent to which the partner makes adjustments in the ongoing relationship in accordance with changing circumstances (e.g., "Flexibility is a characteristic of relationship", "Adjustments to cope with changes", and "Work out a new deal instead of holding", and "If necessary, change the deal set by contract"), provides particular pieces of information that might help each other (e.g., "Exchange information frequently", "If needed, private information is provided", "Regularly exchange needed information", "Any helpful information will be shared", and "Keep each other informed about changes"), and makes efforts toward preserving the relationship (e.g., "Shared responsibility to do the transaction", "Committed to changes for mutual profit", "Do not mind owing each other favours", and "Joint responsibilities for arising problems").

\section{Trust Dimensions}

Interfirm trust in our theory encompasses two essential elements: competence trust and benevolence trust. We adapted the measures of competence trust from Ganesan (1994) and Zaheer, McEvily, and Perrone (1998). A four-item scale measures the degree to which the supplier (buyer) believes that its partner has the required ability to carry out its role effectively and reliably. We adapted the measures of benevolence trust from Ganesan (1994), Morgan and Hunt (1994), and Levin and Cross (2004). The six-item scale measures the extent to which the supplier (buyer) believes that its 
partner acts in accordance with intentions that are beneficial or at least not harmful to the supplier (buyer).

\section{Control Variables}

We controlled for firm age, ownership type (dummy variables: state-owned and nonstate-owned), firm size (number of employees), exchange history, competitive intensity, and market uncertainty. Firm age, type, and size may influence organizational behaviours and decisions. Exchange history indicates the age of the relationship (Ganesan, 1994), which is theoretically related to the development of IOR. We measured this variable with a single item that indicates how long the firms have been doing business together. Environmental uncertainty exerts exchange hazards on the market exchanges (Zhou \& Poppo, 2010) and thus may affect trust between partner and governance choices for interfirm relationships (Williamson, 1985). We measured environmental uncertainty by incorporating competitive intensity and market uncertainty (Noordewier, John, \& Nevin, 1990). The four-item competitive intensity scale captures the availability of alternative products in the market and the intensity of price competition. Market uncertainty consists of four items that assess market changes with respect to sales forecast, customer preference, and technology.

\section{Measurement Validation}

We used the two-step approach to assess the validity of the multi-item measures. First, we ran an exploratory factor analysis for dependence, competence trust, benevolence trust, contractual bonds, relational exchange, competitive intensity, and market uncertainty. Factor solutions were consistent with theoretical postulates. Second, we evaluated the items' psychometric properties by performing confirmatory factor analyses for both the supplier data and the buyer data. The overall measures met the recommended values, and the standardized item loadings on the hypothesized factors were significant. We further conducted tests ensure the discriminant validity of the measures. In Table 1, we report the correlations, means, and standard deviations for all variables used in our analysis.

Table 1: Correlations, Means, and Standard Deviations

\begin{tabular}{|c|c|c|c|c|c|c|c|c|c|c|c|c|c|c|}
\hline & 1 & 2 & 3 & 4 & 5 & 6 & 7 & 8 & 9 & 10 & 11 & 12 & 13 & 14 \\
\hline 1.Firm age & $N A$ & $-.201^{*}$ & -.021 & $.251^{* *}$ & -.128 & -.130 & .025 & -.097 & .020 & -.026 & -.043 & -.034 & -.048 & -.023 \\
\hline 2.Firm type & $-.274^{* *}$ & $N A$ & -.021 & .020 & .100 & .142 & $.214^{* *}$ & .055 & $.191^{*}$ & $.268^{* *}$ & .126 & .093 & .149 & .063 \\
\hline $\begin{array}{l}\text { 3.Exchange } \\
\text { history }\end{array}$ & -.023 & -.128 & $N A$ & $.170^{*}$ & -.075 & .054 & -.052 & .116 & -.082 & .045 & .065 & .108 & .034 & .031 \\
\hline 4.Firm size & $.410^{* *}$ & .018 & $.183^{*}$ & $N A$ & -.101 & $.161^{*}$ & .066 & .104 & .121 & -.048 & .036 & -.022 & .065 & .035 \\
\hline $\begin{array}{l}\text { 5.Competition } \\
\text { intensity }\end{array}$ & -.035 & -.091 & -.052 & .097 & .837 & $.323^{* *}$ & .154 & .015 & .095 & .154 & .138 & $.173^{*}$ & .044 & $.161^{*}$ \\
\hline $\begin{array}{l}\text { 6.Market } \\
\text { uncertainty }\end{array}$ & .029 & .040 & .071 & .030 & $.205^{*}$ & .881 & $.353^{* *}$ & .082 & $.301^{* *}$ & -.012 & $.187^{*}$ & $.237^{* *}$ & $.163^{*}$ & .076 \\
\hline 7.Dependence & .104 & .079 & .103 & -.006 & .111 & $.243^{* *}$ & .942 & $-.188^{*}$ & $.559^{* *}$ & -.047 & $.500^{* *}$ & $.443^{* *}$ & $.435^{* *}$ & $.389^{* *}$ \\
\hline $\begin{array}{l}\text { 8.Benevolence } \\
\text { trust }\end{array}$ & .039 & .039 & -.072 & .138 & -.005 & .080 & $-.226^{* *}$ & .887 & $-.190^{*}$ & $.209^{* *}$ & $.230^{* *}$ & $.311^{* *}$ & $.169^{*}$ & .115 \\
\hline $\begin{array}{l}\text { 9.Competence } \\
\text { trust }\end{array}$ & .047 & .036 & $.163^{*}$ & .044 & $.199^{*}$ & .131 & $.595^{* *}$ & $-.203^{*}$ & .956 & -.056 & $.492^{* *}$ & $.319^{* *}$ & $.478^{* *}$ & $.429^{* *}$ \\
\hline $\begin{array}{l}\text { 10.Contractual } \\
\text { bonds }\end{array}$ & .029 & -.063 & .015 & $.174^{*}$ & -.083 & $.190^{*}$ & -.098 & $.210^{* *}$ & -.055 & .947 & .065 & .031 & .040 & .100 \\
\hline $\begin{array}{l}\text { 11. Relational } \\
\text { exchanges }\end{array}$ & .019 & -.002 & .089 & .056 & $.167^{*}$ & $.227^{* *}$ & $.486^{* *}$ & $.210^{* *}$ & $.543^{* *}$ & .142 & .929 & $.769^{* *}$ & $.901^{* *}$ & $.849^{* *}$ \\
\hline 12.Flexiblity & -.005 & -.036 & .010 & .092 & .153 & .089 & $.202^{*}$ & $.323^{* *}$ & $.277^{* *}$ & .096 & $.780^{* *}$ & .882 & $.521^{* *}$ & $.486^{* *}$ \\
\hline $\begin{array}{l}\text { 13.Information } \\
\text { sharing }\end{array}$ & .071 & -.044 & .131 & .031 & .084 & $.259^{* *}$ & $.534^{* *}$ & .035 & $.623^{* *}$ & .119 & $.855^{* *}$ & $.467^{* *}$ & .922 & $.679^{* *}$ \\
\hline
\end{tabular}




\begin{tabular}{lllllllllllllll} 
14.Solidarity & -.024 & .074 & .071 & .022 & $.188^{*}$ & $.206^{* *}$ & $.454^{* *}$ & $.194^{*}$ & $.431^{* *}$ & .140 & $.868^{* *}$ & $.538^{* *}$ & $.630^{* *}$ & .879 \\
Mean & 15.067 & $N A$ & 4.121 & 365.054 & 4.716 & 3.896 & 4.393 & 4.577 & 4.536 & 5.129 & 5.049 & 5.213 & 4.862 & 5.070 \\
SD & 7.425 & NA & 2.478 & 748.701 & 1.107 & 1.168 & 1.325 & 1.265 & 1.325 & 1.207 & 0.915 & 0.955 & 1.226 & 1.047 \\
\hline
\end{tabular}

Notes: ${ }^{* *} p<.01 ;{ }^{*} p<.05 ; 2$-tailed test; the diagonal elements were Cronbach's alpha coefficients; the upper-right triangle elements were the correlations for buyer side data, $\mathrm{N}_{\mathrm{B}}=157$; the lower-left triangle elements were the correlations for supplier side data, $\mathrm{N}_{\mathrm{S}}=157$; NA = not applicable; Statistics of mean and standard deviation(SD) are for the whole sample $(\mathrm{N}=314)$.

\section{Common Method Variance}

We tried to eliminate common method variance (CMV) by (1) collecting data from both sides of the supplier-buyer dyads, (2) having more than one person answer the questionnaire as much as possible, (3) using the matched data and including in the supplier model several moderators (e.g., the buyer's dependence) measured by the buyer's self-reported scores rather than the supplier's perceptions ( $\mathrm{Su}$ et al., 2009), and (4) incorporating both the supplier data and the buyer data into one dyadic model (Kenny et al., 2006).

\section{Results}

\section{Data Analysis}

Given the dyadic data in which the responses of the two actors in a dyad may be correlated, we employed the APIM for our hypothesis testing for two reasons (Kenny et al., 2006). First, the APIM can estimate and solve the problem of nonindependence (i.e., the correlation of responses between the two actors in a dyad that leads to biased estimates) in dyadic studies, which has largely been neglected in the interfirm relationship literature. Second, it can simultaneously estimate the actor effect and the partner effect of the supplier-buyer dyad and further evaluate the interaction effect between them in the structural equation model. Figure 2 illustrates a typical APIM.

Figure 2: The Illustration of APIM

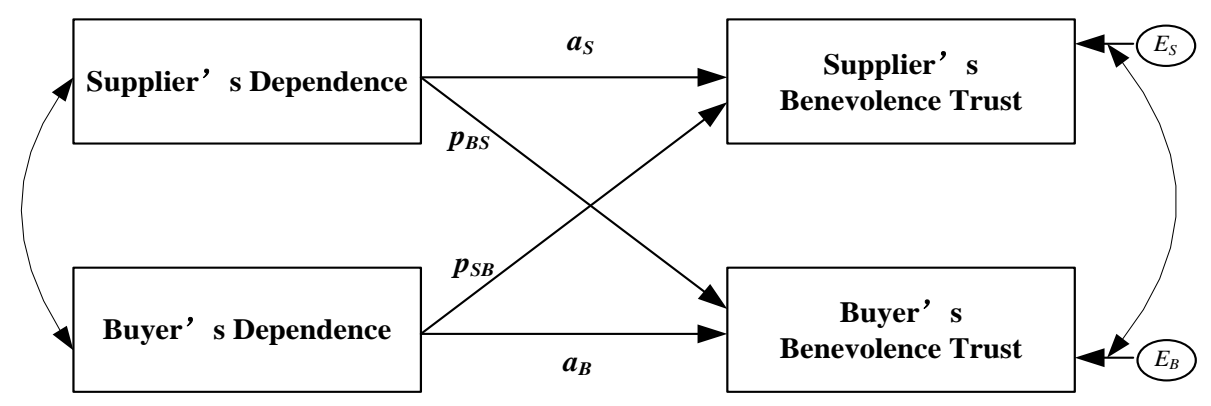

As Figure 2 shows, an actor effect, as indicated by the path coefficient as (aв), occurs when a supplier's (buyer's) score on a predictor variable, such as $X_{\mathrm{S}}\left(\mathrm{X}_{\mathrm{B}}\right)$, affects the same supplier's (buyer's) score on an outcome variable, such as $\mathrm{Y}_{\mathrm{S}}\left(\mathrm{Y}_{\mathrm{B}}\right)$. A partner effect, as indicated by the path coefficient $\mathrm{p}_{\mathrm{BS}}$ ( $\mathrm{p}_{\mathrm{SB}}$ ), occurs when a supplier's (buyer's) score on a predictor variable, such as $\mathrm{X}_{\mathrm{S}}\left(\mathrm{X}_{\mathrm{B}}\right)$, affects its buyer's (supplier's) score on an outcome variable, such as $\mathrm{Y}_{\mathrm{B}}\left(\mathrm{Y}_{\mathrm{S}}\right)$. In addition, we added two correlations 
(between $\mathrm{X}_{\mathrm{S}}$ and $\mathrm{X}_{\mathrm{B}}$ and between $\mathrm{E}_{\mathrm{S}}$ and $\mathrm{E}_{\mathrm{B}}$, the error terms) to the model to address the degree of nonindependence.

We chose SEM to estimate the APIM. The SEM for the APIM estimation in our study incorporated three parts: (1) three predictor variables (i.e., supplier's dependence, buyer's dependence, and their interaction term), (2) four mediators (i.e., supplier's benevolence and competence trust and buyer's benevolence and competence trust), and (3) four outcome variables (i.e., supplier's contractual bonds and relational exchanges and buyer's contractual bonds and relational exchanges). Predictor variables were correlated with each other, the error terms of the mediators were correlated, and the error terms of the outcome variables were also correlated. Table 2 summarizes the results of the SEM for the APIM estimation.

Table 2: Summary of Results of the SEM for the APIM Estimation

\begin{tabular}{|c|c|c|c|c|c|c|c|c|}
\hline \multirow{3}{*}{$\begin{array}{l}\text { Base Model } \\
\text { SDependence }\end{array}$} & \multicolumn{8}{|c|}{ APIM } \\
\hline & \multirow{2}{*}{$\begin{array}{l}\text { SContract } \\
.07 \\
(0.91)\end{array}$} & & \multicolumn{2}{|l|}{ SRelX } & \multicolumn{2}{|l|}{ BContract } & \multicolumn{2}{|l|}{ BRelX } \\
\hline & & & \multicolumn{2}{|l|}{$\begin{array}{l}.14 * \\
(1.98)\end{array}$} & \multicolumn{2}{|l|}{$\begin{array}{l}-.11 \\
(-1.48)\end{array}$} & \multicolumn{2}{|l|}{$\begin{array}{l}.05 \\
(0.72)\end{array}$} \\
\hline BDependence & $\begin{array}{l}(0.91) \\
-.13 \\
(-1.74)\end{array}$ & & $\begin{array}{l}(1.98) \\
-.15^{*} \\
(-2.11)\end{array}$ & & $\begin{array}{l}(-1.48) \\
-.05 \\
(-0.73)\end{array}$ & & $\begin{array}{l}(0.12) \\
.39^{* * *} \\
(6.45)\end{array}$ & \\
\hline Model Fit & \multicolumn{8}{|c|}{$\chi^{2}=550.30, d f=288$, RMSEA $=0.076, \mathrm{CFI}=.93, \mathrm{NFI}=.88, \mathrm{TLI}=.92$} \\
\hline $\begin{array}{l}\text { Mediating Effect } \\
\text { Model }\end{array}$ & SBenTrust & SComTrust & BBenTrust & BComTrust & SContract & SRelX & BContract & BRelBev \\
\hline SDependence & $\begin{array}{l}-.17^{* *} \\
(-2.90)\end{array}$ & $\begin{array}{l}.74^{* * *} \\
(8.42)\end{array}$ & $\begin{array}{l}.22^{*} \\
(2.30)\end{array}$ & $\begin{array}{l}-.06 \\
(-0.75)\end{array}$ & $\begin{array}{l}-.06 \\
(-0.51)\end{array}$ & $\begin{array}{l}.34^{* * *} \\
(4.52)\end{array}$ & $\begin{array}{l}.17 \\
(1.63)\end{array}$ & $\begin{array}{l}-.06 \\
(-0.82)\end{array}$ \\
\hline BDependence & $\begin{array}{l}-.06 \\
(-1.26)\end{array}$ & $\begin{array}{l}-.11 \\
(-1.54)\end{array}$ & $\begin{array}{l}-.22 * * \\
(-2.58)\end{array}$ & $\begin{array}{l}.61^{* * * *} \\
(7.88)\end{array}$ & $\begin{array}{l}-.13 \\
(-1.48)\end{array}$ & $\begin{array}{l}-.13^{*} \\
(-2.30)\end{array}$ & $\begin{array}{l}.00 \\
(0.04)\end{array}$ & $\begin{array}{l}.26 \\
(4.12)\end{array}$ \\
\hline SBenTrust & & & & & $\begin{array}{l}.39^{*} \\
(2.51)\end{array}$ & $\begin{array}{l}.54^{* * *} \\
(4.52)\end{array}$ & $\begin{array}{l}-.05 \\
(-0.34)\end{array}$ & $\begin{array}{l}-.23^{*} \\
(-2.10)\end{array}$ \\
\hline SComTrust & & & & & $\begin{array}{l}.04 \\
(0.39)\end{array}$ & $.32^{* * * *}$ & $\begin{array}{l}-.19^{*} \\
(-2.22)\end{array}$ & .04 \\
\hline BBenTrust & & & & & $\begin{array}{l}.00 \\
(0.01)\end{array}$ & $\begin{array}{l}-.08 \\
(-1.70)\end{array}$ & $\begin{array}{l}.20^{* *} \\
(2.88)\end{array}$ & $\begin{array}{l}.27^{* * * *} \\
(5.27)\end{array}$ \\
\hline BComTrust & & & & & $\begin{array}{l}.05 \\
(0.59)\end{array}$ & $\begin{array}{l}.05 \\
(0.98)\end{array}$ & $\begin{array}{l}-.05 \\
(-0.59)\end{array}$ & $\begin{array}{l}.29^{* * * *} \\
(4.77)\end{array}$ \\
\hline Model Fit & \multicolumn{8}{|c|}{$\chi^{2}=1598.16, d f=952$, RMSEA $=0.066, \mathrm{CFI}=.93, \mathrm{NFI}=.86, \mathrm{TLI}=.92$} \\
\hline $\begin{array}{l}\text { Moderating Effect } \\
\text { Model }\end{array}$ & SBenTrust & SComTrust & BBenTrust & BComTrust & SContract & SRelX & BContract & BRelX \\
\hline SDependence & $\begin{array}{l}-.21^{* *} \\
(-2.86)\end{array}$ & $\begin{array}{l}.96 * * * \\
(8.33)\end{array}$ & $\begin{array}{l}.29^{*} \\
(2.43)\end{array}$ & $\begin{array}{l}-.07 \\
(0.65)\end{array}$ & $\begin{array}{l}-.06 \\
(-0.43)\end{array}$ & $\begin{array}{l}.44^{* * * *} \\
(4.47)\end{array}$ & $\begin{array}{l}.19 \\
(1.38)\end{array}$ & $\begin{array}{l}-.10 \\
(-0.96)\end{array}$ \\
\hline BDependence & $\begin{array}{l}-.08 \\
(-1.18)\end{array}$ & $\begin{array}{l}-.13 \\
(-1.31)\end{array}$ & $\begin{array}{l}-.28 \\
*(-2.42)\end{array}$ & $\begin{array}{l}.86^{* * * *} \\
(\mathbf{7 . 4 3})\end{array}$ & $\begin{array}{l}-.18 \\
(-1.44)\end{array}$ & $\begin{array}{l}-.18^{*} \\
(-2.19)\end{array}$ & $\begin{array}{l}-.01 \\
(-0.07)\end{array}$ & $\begin{array}{l}.35^{* *} \\
*(3.93)\end{array}$ \\
\hline SBDependence & $\begin{array}{l}.07 \\
(0.92)\end{array}$ & $\begin{array}{l}.28^{* *} \\
(2.81)\end{array}$ & $\begin{array}{l}.22^{*} \\
(2.05)\end{array}$ & $\begin{array}{l}.16 * \\
(1.98)\end{array}$ & $\begin{array}{l}.02 \\
(0.15)\end{array}$ & $.05(0.65)$ & $\begin{array}{l}-.11 \\
(-1.01)\end{array}$ & $\begin{array}{l}-.06 \\
(-0.75)\end{array}$ \\
\hline SBenTrust & & & & & $\begin{array}{l}.39^{*} \\
(2.48)\end{array}$ & $\begin{array}{l}.53^{* * * *} \\
(4.48)\end{array}$ & $\begin{array}{l}-.03 \\
(-0.22)\end{array}$ & $\begin{array}{l}-.22^{*} \\
(-2.03)\end{array}$ \\
\hline SComTrust & & & & & $\begin{array}{l}.03 \\
(0.31)\end{array}$ & $.31^{* * *}$ & $\begin{array}{l}-.17 \\
(-1.86)\end{array}$ & $.05(0.81)$ \\
\hline BBenTrust & & & & & $\begin{array}{l}.00 \\
(-0.01)\end{array}$ & $\begin{array}{l}-.08 \\
(-1.74)\end{array}$ & $\begin{array}{l}.20^{* *} \\
(2.98)\end{array}$ & $\begin{array}{l}.27^{* * * *} \\
(\mathbf{5 . 3 0})\end{array}$ \\
\hline BComTrust & & & & & $\begin{array}{l}.05 \\
(0.54)\end{array}$ & $\begin{array}{l}.04 \\
(0.83)\end{array}$ & $\begin{array}{l}-.03 \\
(-0.40)\end{array}$ & $\begin{array}{l}.30^{* * *} \\
(4.83)\end{array}$ \\
\hline Model Fit & \multicolumn{8}{|c|}{$\chi^{2}=1819.13, d f=1128, \mathrm{RMSEA}=0.063, \mathrm{CFI}=.93, \mathrm{NFI}=.89, \mathrm{TLI}=.93$} \\
\hline
\end{tabular}

Notes: $* \mathrm{p}<.05, * * \mathrm{p}<.01, * * * \mathrm{p}<.001$; the numbers in parentheses are $\mathrm{t}$-values; SDependence = supplier's dependence on buyer; BDependence = buyer's dependence on supplier; SBDependence = SDependence*BDependence; SBenTrust = supplier's trust in buyer's benevolence; SComTrust = supplier's trust in buyer's competence; BBenTrust = buyer's trust in supplier's benevolence; BComTrust = buyer's trust in supplier's competence; RelX = relational exchanges. 


\section{Hypothesis Testing}

\section{Dependence Structure and Governance Choices}

Because the SEM for the APIM estimation included latent variables and multiple mediators, following Frazier, Tix, and Barron's (2004) suggestions, we calculated the total effect of the supplier's dependence on its contractual bonds as $-.10(p>.10)$. Likewise, the total effect of the supplier's dependence on its relational exchanges was $.46(p<.001)$, and the total effects of the buyer's dependence on its contractual bonds and relational exchanges was $-.05(p>.10)$ and $.39(p<.001)$, respectively. With regard to the partner effect, the total effect of the buyer's dependence on the supplier's contractual bonds and relational exchanges was $-.13(p>.05)$ and $-.15(p<.01)$, respectively, and the total effect of the supplier's dependence on the buyer's contractual bonds and relational exchanges was $.09(p>.10)$ and $.05(p>.10)$, respectively. These results indicate that the supplier's (buyer's) dependence has a positive effect on its choice of relational governance but no effect on its choice of contractual bonds with its partner, in support of Hypothesis $1 \mathrm{~b}$ but not Hypothesis 1a.

\section{Mediating Effects of Trust Dimensions}

The results of the mediating effect model in Table 2 show that as the supplier's dependence on the buyer increases, the supplier trusts the buyer more in its competence $(b=.74, p<.001)$ but less in its benevolence $(b=-.17, p<.01)$. The buyer's data also show a similar pattern. As the dependence on the supplier increases, the buyer trusts the supplier more in its competence $(b=.61, p<.001)$ but less in its benevolence $(b=-.22, p<.01)$. Thus, Hypothesis 2 is fully supported.

The SEM results of the APIM estimation as shown in Table 2 indicate that trust dimensions have different effects on the governance choices. Specifically, trust in the buyer's benevolence drives the supplier to engage in both contractual bonds $(b=.39$, $p<.05)$ and relational exchanges $(b=.54, p<.001)$, while trust in the buyer's competence motivates the supplier to conduct more relational exchanges $(b=.32, p<$ $.001)$ with the buyer but has no impact on its motivation to use contractual bonds $(b=$ $.04, p>.10)$. The buyer's data echo the pattern of the supplier data. As its trust in the supplier's benevolence increases, the buyer conducts more contractual bonds $(b=.20$, $p<.01)$ and relational exchanges $(b=.27, p<.001)$, but when its trust in the supplier's competence increases, the buyer tends to conduct relational exchanges $(b=$ $.29, p<.001)$ but does not develop more contractual bonds with the supplier $(b=-$ $.05, p>.10)$. Therefore, Hypothesis $3 \mathrm{a}$ is fully supported; Hypothesis $3 \mathrm{~b}$ is also supported, but benevolence trust also motivates relational exchanges. An explanation for this might be that relational exchange facilitates the contracting process (Luo, 2002).

\section{Moderating Effect}

The results, shown as the moderating effect model in Table 2, reveal that the interaction effect between the supplier's dependence and the buyer's dependence is significant for the supplier's competence trust $(b=.28, p<.01)$ but not for the supplier's benevolence trust $(b=.07, p>.10)$, in support of Hypothesis 4a but not Hypothesis 4b. Furthermore, the buyer's data show that the interaction term was 
significant for both the buyer's competence trust $(b=.16, p<.05)$ and benevolence trust $(b=.22, p<.05)$. An explanation for this might be that in a typical buyer's Chinese market, the perceived buyer dependence may not mitigate the supplier's fear of the buyer's power in taking unilateral actions in the relationship.

\section{Discussion}

\section{Theoretical Contributions}

How dependence structure affects governance choices in the supplier-buyer relationship remains debatable and uncharted. Our study represents the first attempt to inform this debate through an empirical investigation of the mediating effect of trust dimensions and the problem of nonindependence in supplier-buyer dyads. In addition, given the dyadic nature of the supplier-buyer relationship, we argue that the onesided data in prior research may have missed the partner effect in model estimations - that is, the other party in the dyad may also affect the outcome variables in the model. We calibrate an APIM (Kenny et al., 2006) to estimate simultaneously both the supplier and the buyer effects. Our findings shed new light on firm governance choice behavior and supplier-buyer relationship management.

The theoretical argument that dependence structure affects trust production has long been proposed (Rousseau et al., 1998; Sheppard \& Sherman, 1998), but little empirical evidence has been provided. As Weitz and Jap (1995) aptly summarize, a firm will try to develop relationships with other firms offering synergistic capabilities it does not possess (competence concerns) and those having a reputation and history of fairness and consideration (benevolence concerns). Our study is the first to causally link dependence and trust and empirically verify such inherent relationship. In light of Emerson's (1962) definition of dependence and by decomposing trust into its dimensions (benevolence trust and competence trust), we find that when the supplier depends more on the buyer, it trusts the buyer more in its competence, because the supplier must obtain critical resources and support from the buyer, but less in its benevolence, because the supplier fears that the buyer will abuse its power.

The aforementioned findings regarding dependence and trust dimensions contribute to reconciling the long-standing debatable effect of dependence structure on governance choice (e.g., Lusch \& Brown, 1996; Su et al., 2009). We find that trust dimensions mediate the effects of dependence structure on governance choice in different ways. The results support the arguments that the more dependent supplier tends to conduct more relational exchanges with the buyer to build a long-term relationship and that the less dependent supplier tends to develop more contractual bonds with the buyer to ward off performance risks (Gilliland et al., 2010; Kale, 1989; Su et al., 2009). As such, we open the black box that has hidden the intermediate mechanism by which firm dependence concerns generate firm governance strategies.

Another contribution of this study to the literature lies in its dyadic perspective. The estimation of the structural equation model revealed significant partner effects on the actor's variables. We also uncovered some surprising partner effects. For example, the supplier's competence trust had a negative effect on the buyer's use of contractual bonds, while the supplier's benevolence trust had a negative effect on the buyer's use 
of relational exchanges. Such unexpected partner effects may originate from perception errors (Vosgerau, Anderson \& Ross, 2008).

\section{Limitations and Further Research}

We acknowledge several limitations of this study, which suggest directions for further research. First, the cross-sectional data make it impossible to capture relationship development along the dependence-trust-governance logic. Therefore, studies based on sequential data with comparable measures of constructs are needed to capture firm dependence-trust dynamics.

Second, the single-industry sample constrains the generalizability of our findings. Thus, further research should simultaneously collect data from both Western and Chinese marketing channels or channel dyads involving both Western and Chinese partners to generalize our findings across cultures. In addition, the survey data cannot deal with the endogeneity problem in our context and thus the conclusions are not causality but correlation-based. We call for future studies to examine the causal relationships using longitudinal studies or field experiments.

Third, although we collected data from both the supplier and the buyer, the problems of perception errors (Vosgerau et al., 2008) may still exist. In dyadic business relationships, partners may misread their counterparts' relational closeness. The consequences of such inaccurate perceptions can cause the supplier to over trust or under trust the partner, which in turn may affect the optimal governance choices and thus bias our model estimation. Thus, further research should include a measure of the supplier's perception of the buyer's dependence on the supplier to evaluate the potential effect of perception errors. Moreover, integrity-based trust is also an important dimension of trust (Mayer et al. 1995; Ogbeibu et al. 2020) and we see great potential to include such additional dimensions into our model to examine a more comprehensive view of dependence structure, trust dimensions, and governance mechanisms.

Finally, our study is constrained to the dyadic relationship. Further research could extend the study by building theory and modeling the triadic or network relationships. For example, in a triadic relationship, firm dependence may also be determined by its relationship with a third partner. How such triadic dependence determines interfirm trust and how the dimensions of trust affect firm governance modes represent a new direction to investigate supplier-buyer relationships among various partners (e.g., Wathne \& Heide, 2004).

\section{Implications for Asian Business Context}

Our findings shed new light on supplier-buyer relationship management from a dependence-trust-governance perspective, especially in the Asian context. First, given the inherent relationship between dependence and trust, a firm may predict its partner's governance behavior. On the one hand, a less dependent firm may proactively nurture a relational exchange in which the firm reveals its benevolence to its partner to mitigate the partner's fear or suspicion about the firm's power and goodwill. On the other hand, the more dependent firm may need to demonstrate its 
distinct capability and resources to gain its partner's competence trust. Such prescription is especially important in China because in the Chinese psychocultural an actor A may depend on the other actor B because B is more powerful (Zhuang \& Zhou, 2004), indicating a high competence trust. Thus, our managerial implications are very relevant in the Asian context.

Second, firms may take action to proactively increase their own and/or their partners' dependence on the relationship. A less dependent firm may invest more on specific assets to gain its partner's benevolence trust. The firm may also combine contract and relational exchange to enhance its governance legitimacy to attract the dependent partner for a more cooperative relationship (Frazier \& Rody, 1991). The less powerful firm may mitigate its disadvantageous position by taking a more cooperative stance toward the relationship (Ganesan, 1994; Su et al., 2009). For example, in China, the less powerful party is commonly to find a powerful partner to support them, namely, Zhao Kao Shan (Zhang \& Zhou, 2004, p.676). Based on our findings, managers can use relational bonds to develop more informal governance mechanism to elicit the powerful party's benevolence trust in their firm and facilitate cooperation.

Finally, our findings based on a Chinese sample also provide new insights for multinational companies doing business in Asia. In a typical buyer's market in China, in which channel members have more power, suppliers face more constraints in enforcing contracts and thus need to invest more in relational exchanges to balance dependence and build a long-term relationship with the buyers (Luo, 2002). Moreover, in a rationalism-oriented society, firms may need to empower their boundary agents to use personal relationships (e.g., Guanxi) to leverage dependence and, thus, interfirm trust to safeguard the effectiveness of governance ( $\mathrm{Su}$ et al., 2009).

\section{References}

Andaleeb S. S., (1992), Research in marketing, JAI Press, Greenwich.

Anderson J. C., \& Narus, J. A., (1990), "A model of distribution firm and manufacture firm working partnerships", Journal of Marketing, vol. 54, pp. 42-58.

Baron, R. M., \& Kenny, D. A., (1986), "The moderator-mediator variable distinction in social psychological research", Journal of Personality and Social Psychology, vol. 51, pp. 1173-1182.

Benton, W. C., \& Maloni, M., (2005), "The influence of power-driven buyer/seller relationships on supply chain satisfaction", Journal of Operations Management, vol. 23, pp. 1-22.

Brattström, A., Faems, D., \& Mähring, M., (2019), "From trust convergence to trust divergence: Trust development in conflictual interorganizational relationships", Organization Studies, vol. 40, pp. 1685-1711.

Brown, J. R., Lusch, R. F., \& Nicholson, C. Y., (1995), "Power and relationship commitment", Journal of Retailing, vol. 71, pp. 363-392.

Bstieler, L., Hemmert, M., \& Barczak, G., (2017), "The changing bases of mutual trust formation in inter-organizational relationships", Journal of Business Research, vol. 74, pp. 47-54.

Cannon, J. P., \& Perreault, W. D., (1999), "Retailer-seller relationships in business markets", Journal of Marketing Research, vol. 36, pp. 439-460.

Carson, S. J., Madhok, A., \& Wu, T., (2006), "Uncertainty, opportunism, and governance", Academy of Management Journal, vol. 49, pp. 1058-1077. 
Casciaro, T., \& Piskorski, M. J., (2005), "Power imbalance, mutual dependence, and constraint absorption", Administrative Science Quarterly, vol. 50, pp. 167-199.

Chatterji, A. K., Cunningham, C. M., \& Joseph, J. E., (2019), "The limits of relational governance: Sales force strategies in the US medical device industry", Strategic Management Journal, vol. 40, pp. 55-78.

Chiles, T. H., \& McMackin, J., (1996), "Integrating variable risk preferences, trust, and transaction costs economics", Academy of Management Review, vol. 21, pp. 73-99.

Colm, L., Ordanini, A., \& Bornemann T., (2020), "Dynamic governance matching in solution development", Journal of Marketing, vol. 84, pp. 105-124.

Cook, W. L., \& Kenny, D. A., (2005), "The actor-partner interdependence model", International Journal of Behavioural Development, vol. 29, pp. 101-109.

Das, T. K., \& Teng, B., (2001), "Trust, control, and risk in strategic alliances: An integrated framework", Organization Studies, vol. 22, pp. 251-283.

Dekker, H., Donada, C., Mothe, C., \& Nogatchewsky, G., (2019), "Boundary spanner relational behaviour and inter-organizational control in supply chain relationships", Industrial Marketing Management, vol. 77, pp. 143-154.

Doney, P. M., \& Cannon, J. P., (1997), "An examination of the nature of trust in retailer-seller relationships", Journal of Marketing, vol. 61, pp. 35-51.

Dyer, J. H., \& Chu, W., (2003), "The role of trustworthiness in reducing transaction costs and improving performance", Organization Science, vol. 14, pp. 57-68.

Dyer, J. H., \& Singh, H., (1998), "The relational view", Academy of Management Review, vol. 23, pp. 660-679.

Eckerd, A., \& Girth, A. M., (2017), "Designing the buyer-supplier contract for risk management: Assessing complexity and mission criticality", Journal of Supply Chain Management, vol. 53, no. 3, pp. 60-75.

Emerson, R. M., (1962), "Power-dependence relations", American Sociological Review, vol. 27, pp. 31-41.

Frazier, G. L., (1983), "On the measurement of interfirm power in channels of distribution", Journal of Marketing Research, vol. 20, pp. 158-166.

Frazier, P. A., Tix, A. P., \& Barron, K. E., (2004), "Testing moderator and mediator effects in counselling psychology research", Journal of Counselling Psychology, vol. 51, pp. 115134.

Frazier, G. L., \& Rody, R. C., (1991), "The use of influence strategies in interfirm relationships in industrial product channels", Journal of Marketing, vol. 55, pp. 52-69.

Ganesan, S., (1994), "Determinants of long-term orientation in retailer-seller relationships", Journal of Marketing, vol. 59, pp. 1-19.

Gaski, J. F., (1984), "The theory of power and conflict in channels of distribution", Journal of Marketing, vol. 48, pp. 9-29.

Gilliland, D. I., Bello, D. C., \& Gundlach, G. T., (2010), "Control-based channel governance and relative dependence", Journal of the Academy of Marketing Science, vol. 38, pp. 441-455.

Gu, F. F., Kim, N., Tse, D. K., \& Wang, D. T., (2010), "Managing distributors' changing motivations over the course of a joint sales program", Journal of Marketing, vol. 74, pp. $32-47$.

Gulati, R., Sytch, M., (2007), "Dependence asymmetry and joint dependence in IOR", Administrative Science Quarterly, vol. 52, pp. 39-55.

Gulati, R., (1998), "Alliances and networks", Strategic Management Journal, vol. 19, pp. 293-317.

Gustafsson, A., Johnson, M. D., \& Roos, I., (2005), "The effects of customer satisfaction, relationship commitment dimensions, and triggers on customer retention", Journal of Marketing, vol. 69, pp. 210-218.

Heide, J. B., \& John, G., (1988), "The role of dependence balancing in safeguarding transaction-specific assets in conventional channels", Journal of Marketing, vol. 52, pp. 20-35. 
Heide, J. B., \& John, G., (1992), "Do norms matter in marketing relationships?", Journal of Marketing, vol. 56, pp. 32-44.

Heide, J. B., (1994), "Interorganizational governance in marketing channels", Journal of Marketing, vol. 58, pp. 71-85.

Heide, J. B., (2003), "Plural governance in industrial purchasing", Journal of Marketing, vol. 67, pp. 18-29.

Hewett, K., \& Bearden, W. O., (2001), "Dependence, trust, and relational behaviour on the part of foreign subsidiary marketing operations", Journal of Marketing, vol. 65, pp. 5166.

Heyns, M., \& Rothmann, S., (2015), "Dimensionality of trust: An analysis of the relations between propensity, trustworthiness and trust", SA Journal of Industrial Psychology, vol. 41, pp. 1-12.

Hibbard, J. D., Kumar, N., \& Stern, L. W., (2001), "Examining the impact of destructive acts in marketing channel relationships", Journal of Marketing Research, vol. 38, pp. 45-61.

Howard, M., Roehrich, J. K., Lewis, M. A., \& Squire, B., (2019), "Converging and diverging governance mechanisms: The role of (dys) function in long-term inter-organizational relationships", British Journal of Management, vol. 30, pp. 624-644.

Jia, F., \& Yang, Z., (2019), "Perceptual difference of dependence and trust in marketing channel: Reconsideration of dependence measurement", Asian Business \& Management, pp.1-27.

Kale, P., Singh, H., \& Perlmutter, H., (2000), "Learning and protection of proprietary assets in strategic alliances", Strategic Management Journal, vol. 21, pp. 217-237.

Kale, S. H., (1989), "Dealer dependence and influence strategies in a manufacturer-dealer dyad", Journal of Applied Psychology, vol. 74, pp. 379-384.

Kenny, D. A., Kashy, D. A., \& Cook, W., (2006), Dyadic data analysis, Guilford Press, New York.

Kenny, D. A., (1996), "Models of nonindependence in dyadic research", Journal of Social and Personal Relationships, vol. 13, pp. 279-294.

Krishnan, R., Martin, X., \& Noorderhaven, N. G., (2006), "When does trust matter to alliance performance?", Academy of Management Journal, vol. 49, pp. 894-917.

Kujala, J., Lehtimaki, H., \& Pucetaite, R., (2015), "Trust and distrust constructing unity and fragmentation of organisational culture", Journal of Business Ethics, vol. 139, pp.701716.

Kumar, N., Scheer, L. K., \& Steenkamp, J-BEM., (1995), "The effects of perceived interdependence on dealer attitudes", Journal of Marketing Research, vol. 32, pp. 348356.

Kumar, N., Stern, L. W., \& Anderson, J. C., (1993), "Conducting interorganizational research using key informants", Academy of Management Journal, vol. 36, pp. 1633-1651.

Leonidou, L. C., Aykol, B., Spyropoulou, S., \& Christodoulides, P., (2019), "The power roots and drivers of infidelity in international business relationships", Industrial Marketing Management, vol. 78, pp.198-212.

Levin, D. Z., \& Cross, R., (2004), "The strength of weak ties you can trust", Management Science, vol. 50, pp. 1477-1490.

Li, J., Zhou, C., \& Zajac, E. J., (2009), "Control, collaboration, and productivity in international joint ventures: Theory and evidence", Strategic Management Journal, vol. 30, pp. 865-884.

Luhmann, N., (1979), Trust and power, John Wiley and Sons, Chichester.

Lui, S. S., \& Ngo, H-Y., (2004), "The role of trust and contractual safeguards on cooperation in non-equity alliances", Journal of Management, vol. 30, pp. 471-485.

Luo, Y., (2002), "Contract, cooperation, and performance in international joint ventures", Strategic Management Journal, vol. 23, pp. 903-920.

Lusch, R. F., \& Brown, J. R., (1996), "Interdependency, contracting, and relational behaviour in marketing channels", Journal of Marketing, vol. 60, pp. 19-33. 
Malhotra, D., \& Lumineau, F., (2011), "Trust and collaboration in the aftermath of conflict: The effects of contract structure", Academy of Management Journal, vol. 54, pp. 981998.

Mayer, K. J., \& Argyres, N. S., (2004), "Learning to contract", Organization Science, vol. 15, pp. 394-410.

McEvily, B., \& Zaheer, A., (2006), Does trust still matter?, Edward Elgar Publishing, Cheltenham.

McEvily, B., Zaheer, A., \& Kamal, D. K. F., (2017), "Mutual and exclusive: Dyadic sources of trust in interorganizational exchange", Organization Science, vol. 28, pp.74-92.

Morgan, R. M., \& Hunt, S. D., (1994), "The commitment-trust theory of relationship marketing", Journal of Marketing, vol. 28, pp. 20-38.

Noordewier, T. G., John, G., \& Nevin, J. R., (1990), "Performance outcomes of purchasing arrangements in industrial retailer-vendor relationships", Journal of Marketing, vol. 54, pp. 80-93.

Nooteboom, B., (1996), "Trust, opportunism and governance", Organization Studies, vol. 17, pp. $985-1010$.

North, D. C., (1990), Institutions, institutional change, and economic performance, Cambridge University Press, Cambridge.

Ogbeibu, S., Senadjki, A., \& Peng, T. L., (2018), "An organisational culture and trustworthiness multidimensional model to engender employee creativity", American Journal of Business, vol. 33, pp.179-202.

Ogbeibu, S., Senadjki, A., Emelifeonwu, J., \& Vohra, P. S., (2020), "Inspiring creativity in diverse organizational cultures: An expatriate integrity dilemma", FIIB Business Review, pp. 1-14.

Oliveira, N., \& Lumineau, F., (2019), "The dark side of interorganizational relationships: An integrative review and research agenda", Journal of Management, vol. 45, pp. 231-261.

Palmatier, R. W., Dant, R. P., \& Grewal, D., (2007), "A comparative longitudinal analysis of theoretical perspectives of IOR performance", Journal of Marketing, vol. 71, pp. 172194.

Payan, J. M., \& McFarland, R. G., (2005), "Decomposing influence strategies", Journal of Marketing, vol. 69, pp. 66-79.

Petersen, K. J., Handfield, R. B., Lawson, B., \& Cousins, P. D., (2008), "Buyer dependency and relational capital formation: The mediating effects of socialization processes and supplier integration", Journal of Supply Chain Management, vol. 44, no. 4, pp. 53-65.

Pfeffer, J., \& Salancik, G. R., (1978), The external control of organizations, Harper Row, New York.

Podsakoff, P. M., MacKenzie, S. B., Lee, J. Y., \& Podsakoff, N. P., (2003), "Common method biases in behavioural research", Journal of Applied Psychology, vol. 88, pp. 879-903.

Poppo, L., \& Zenger, T., (2002), "Do formal contracts and relational governance function as substitutes or complements?", Strategic Management Journal, vol. 23, pp. 707-725.

Ralston, D. A., Lee, C. H., Perrewe, P. L., Deusen, C. V., Vollme, G. R., Maignan, I., Tang, M., Wan, P., \& Rossi, A. M., (2010), "A multi-society examination of the impact of psychological resources on stressor-strain relationships", Journal of International Business Studies, vol. 41, pp. 652-670.

Ramaseshan, B., Yip, L. S. C., \& Pae, J. H., (2006), "Power, satisfaction, and. relationship commitment in Chinese store-tenant relationship and their impact on performance", Journal of Retailing, vol. 82, pp. 63-70.

Reuer, J. J., \& Ariño, A., (2007), "Strategic alliance contracts: Dimensions and determinants of contractual complexity", Strategic Management Journal, vol. 28, pp. 313-330.

Ring, P. S., \& Van de Ven, A. H., (1992), "Structuring cooperative relationships between organizations", Strategic Management Journal, vol. 13, pp. 483-498.

Ring, P. S., \& Van de Ven, A. H., (2019), "Relational bonds underlying cooperative interorganizational relations in different societal contexts. managing inter-organizational 
collaborations: Process views", Research in the Sociology of Organizations, vol. 64, pp.13-37.

Roehrich, J. K., Selviaridis, K., Kalra, J., Van der Valk, W., \& Fang, F., (2020), "Interorganizational governance: A review, conceptualisation and extension", Production Planning \& Control, pp. 1-17.

Rousseau, D., Sitkin, M., Burt, R., \& Camerer, C., (1998), "Not so different after all: A crossdiscipline view of trust", Academy of Management Review, vol. 23, pp. 393-404.

Saxton, T., (1997), "The effects of partner and relationship characteristics on alliance outcomes", Academy of Management Journal, vol. 40, pp. 443-461.

Sheppard, B. H., \& Sherman, D. M., (1998), "The grammars of trust", Academy of Management Review, vol. 23, pp. 422-437.

Simonin, B., (1999), "Ambiguity and the process of knowledge transfer in strategic alliances", Strategic Management Journal, vol. 20, pp. 595-623.

Su, C., Yang, Z., Zhuang, G., Zhou, N., \& Dou, W., (2009), "Interpersonal influence as an alternative channel communication behaviour in emerging markets: The case of China", Journal of International Business Studies, vol. 40, pp. 668-689.

Teece, D. J., Pisano, G., \& Shuen, A., (1997), "Dynamic capabilities and strategic management", Strategic Management Journal, vol. 18, pp. 509-533.

Terpend, R., \& Krause, D. R., (2015), "Competition or cooperation? Promoting supplier performance with incentives under varying conditions of dependence", Journal of Supply Chain Management, vol. 51, no. 4, pp. 29-53.

Villena, V. H., Choi, T. Y., \& Revilla, E., (2019), "Revisiting interorganizational trust: Is more always better or could more be worse?", Journal of Management, vol. 45, pp. 752-785.

Vosgerau, J., Anderson, E., \& Ross, W. T. Jr., (2008), "Can inaccurate perceptions in B2B relationships be beneficial?", Marketing Science, vol. 27, pp. 205-224.

Wathne, K. H., \& Heide, J. B., (2004), "Relationship governance in a supply chain network", Journal of Marketing, vol. 68, no. 1, pp. 73-89.

Weitz, B. A., \& Jap, S. D., (1995), "Relationship marketing and distribution channels", Journal of the Academy of Marketing Science, vol. 23, pp. 305-320.

Williamson, O. E., (1985), The economic institutions of capitalism, Free Press, New York.

Woolthuis, R. K., Hillebrand, B., \& Nooteboom, B., (2005), "Trust, contract and relationship development”, Organization Studies, vol. 26, pp. 813-840.

Xia, J., (2011), "Mutual dependence, partner substitutability, and repeated partnership: The survival of cross-border alliances", Strategic Management Journal, vol. 32, pp. 229253.

Yakovleva, M., Reilly, R. R., \& Werko, R., (2010), "Why do we trust? Moving beyond individual to dyadic perceptions", Journal of Applied Psychology, vol. 95, pp. 79-91.

Zaheer, A., McEvily, B., \& Perrone, V., (1998), "Does trust matter?", Organization Science, vol. 9, pp. 141-159.

Zheng, X., Griffith, D. A., Ge, L., \& Benoliel, U., (2020), "Effects of contract ambiguity in interorganizational governance", Journal of Marketing, forthcoming, pp, 1-21.

Zhong, W., Su, C., Peng, J., \& Yang, Z., (2017), "Trust in interorganizational relationships: A meta-analytic integration", Journal of Management, vol. 43, pp.1050-1075.

Zhou, K. Z., \& Poppo, L., (2010), "Exchange hazards, relational reliability, and contracts in China", Journal of International Business Studies, vol. 41, pp. 861-881.

Zhuang, G., \& Zhou, N., (2004), "The relationship between power and dependence in marketing channels: A Chinese perspective", European Journal of Marketing, vol. 38, pp. 675-693. 